\title{
SURFACE VELOCITY DYNAMICS OF SAMUDRA TAPU GLACIER, INDIA FROM 2013 TO 2017 USING LANDSAT-8 DATA
}

\author{
R. Sahu ${ }^{1, *}$, R. D. Gupta ${ }^{2}$ \\ ${ }^{1}$ GIS Cell, Motilal Nehru National Institute of Technology Allahabad, Prayagraj -211004, U.P., India - rgi1503@ mnnit.ac.in \\ ${ }^{2}$ Civil Engineering Department, Motilal Nehru National Institute of Technology Allahabad, Prayagraj -211004, U.P., India - \\ rdg@mnnit.ac.in
}

Commission V, WG V/7 \& Commission IV, WG IV/6

KEY WORDS: Surface Velocity, Glacier, Cross-correlation, PAN Data, Landsat-8 OLI

\begin{abstract}
:
In glacier dynamics, surface velocity of glacier is an important parameter to understand the behaviour of glacier in absence of mass balance and long-term glacier area change information. In present study, surface velocity of Samudra Tapu Glacier, India is estimated using freely available Landsat-8 OLI (PAN) images during 2013-2017. To estimate surface velocity, open source COSICorr tool is used which is based on cross-correlation algorithm. Maximum annual surface velocity estimated is $55.68 \pm 4.01 \mathrm{~m} / \mathrm{year}$ during 2015- 2016 while the minimum surface velocity being $44.99 \pm 4.67 \mathrm{~m} /$ year in 2016-2017. The average annual velocity during 2013-2017 was 50.51 $\pm 4.49 \mathrm{~m} /$ year which is higher than other glaciers in Chandra basin. The variation in annual surface velocity is analysed which not only depends on mass loss but also on temperature, pressure and internal drainage. Further, as one moves opposite to glacier terminus, the surface velocity increases with the increase in glacier elevation and slope. The higher surface velocity can be attributed to the fact that Samudra Tapu is a top-heavy glacier based on HI index analysis having larger accumulation area along with high glacier ice-thickness.
\end{abstract}

\section{INTRODUCTION}

Glaciers are highly sensitive to climate change and an increase in glaciers retreat rate is observed all over the world due to climate change since last decade (Azam et al., 2018). Different parameters i.e. glacier area, surface velocity and mass balance have been used for glacier monitoring. Glacier surface velocity is one of important parameters to understand behaviour of glacier in absence of mass balance and long-term glacier area change information. Glacier surface velocity also helps to understand glacier retreat and advance, mass balance changes, ice thickness estimation, early warning of glacier lake outburst flood and change in strain rate (Dehecq et al., 2019; Gantayat et al., 2014; Paul et al., 2017; Yan et al., 2018). Therefore, it is necessary to study surface velocity of the glaciers to increase the knowledge in glacier dynamics.

Conventionally, surface velocity of glacier is computed by drilling the stakes on the glacier and using Global Positioning System (GPS). But these methods are time consuming and costly. However, most of the glaciers in high mountain Asia are inaccessible due to rugged topography (Dehecq et al., 2015). The remote sensing data provide alternative way to monitor the glacier surface velocity on daily to yearly basis (Heid and Kääb, 2012). Optical and microwave remote sensing are generally used in surface velocity estimation. Optical remote sensing data are now-a-days commonly used for surface velocity estimation by researchers using feature tracking method due to availability of data from large number of optical sensor, from low resolution to high resolution (Bhushan et al., 2018; Paul et al., 2017; Sun et al., 2017) which is even freely available from some sensors. MODIS, ASTER, Landsat ETM+, TM, OLI and Sentinel-2 MSI sensors can be used for surface velocity estimation. The active microwave gives all weather data which can be used in SAR interferometry and feature tracking method for surface velocity estimation (Kumar et al., 2013; Yasuda and Furuya, 2013; Yellala et al., 2019).

Various studies have been carried out previously using optical and SAR data. Quincey et al. (2009) estimated surface velocity of Baltoro glacier in central Karakoram during 1992-2008, and correlated the same with climate change. Dehecq et al. (2015) used Landsat TM and ETM+ images and estimated surface velocity of glaciers in entire Karakoram glacier during 19992001. Paul et al. (2017) estimated surface velocity of Hispar Glacier in Karakoram using Landsat ETM+, Landsat OLI, RADARSAT-2 and Sentinel-1 data during 2013-2015 and correlated the same with glacier surging behaviour. In Chandra basin, Garg et al. (2017) estimated surface velocity of Chhota Shigri, Bara Shigri and Sakchum glacier during 2002-2003 and 2013-2014 and compared with mass balance during the same year using ASTER data. Tiwari et al. (2014) estimated surface velocity of Chhota Shigri Glacier during 2003-2009 and compared with field based data using ASTER satellite images. Patel et al. (2019) used particle image Velocimetry technique to analyse surface velocity of Chhota Shigri Glacier and compared with field based data. Sahu and Gupta (2019) estimated surface velocity of Gepang Gath, Hamtah, Chhota Shigri and Bara Shigri glaciers using Landsat ETM+ and OLI data during 19992017.

Researchers have carried out various studies on Samudra Tapu Glacier. Mukherjee et al. (2018) estimated glacier area and length change of Samudra Tapu Glacier from 1971 to 2015 and correlated this with mass balance in the same period. Vijay and

Corresponding author 
Braun (2016) analysed mass balance of all glaciers along with Samudra Tapu Glacier in Chandra Basin during 2000-2013. Pandey and Venkataraman (2013) analysed the glacier area and length change of Samudra Tapu Glacier during 1980-2010. Kulkarni et al. (2006) estimated the glacier retreat rate of Samudra Tapu Glacier during 1962-2000. Thus, all these studies related to Samudra Tapu Glacier have been carried out in reference to glacier area, length change and mass balance. This is an important glacier because it has pro-glacial lake in its terminus which is prone to outburst flood (Prakash and Nagarajan, 2018). However, studies related to the estimation of surface velocity of Samudra Tapu Glacier have not been taken up in the past even though surface velocity is also an important parameter in the study of glacier dynamics. Hence, in the present work, surface velocity of Samudra Tapu Glacier is analysed using freely available Landsat- 8 OLI (PAN) images during 2013-2017 to fill the knowledge gap for Samudra Tapu Glacier in Chandra basin. For this purpose, open source COSICorr tool, a freely available plug-in for commercial ENVI software and based on cross-correlation algorithm, is used for estimation of surface velocity.

\section{STUDY AREA}

Samudra Tapu Glacier is selected for inter-annual surface velocity analysis during 2013 to 2017. Samudra Tapu Glacier is located in Chandra basin, Western Himalaya (figure 1). This glacier is a second largest glacier in terms of area in Chandra basin. The central longitude and latitude of Samudra Tapu Glacier is $77.41^{\circ} \mathrm{E}$ and $32.48^{\circ} \mathrm{N}$ respectively. Total glacier area is $80.01 \mathrm{~km}^{2}$ and its minimum, maximum and median elevation is 4237,6098 , and $5254 \mathrm{~m}$ a.s.l. respectively (RGI inventory). Samudra Tapu Glacier falls in monsoon arid transition zone and receives precipitation due to Indian summer monsoon and midlatitude westerlies (Bajpai, 1995).

\section{DATA USED}

In present study, freely available Panchromatic (PAN) data of Landsat-8 Operational Land Imager (OLI) sensor is used to estimate surface velocity of Samudra Tapu Glacier. Landsat- 8 satellites were launched on February 11, 2013 and is operational. One scene of OLI image covers $185 \mathrm{~km}$ x $170 \mathrm{~km}$ area with revisit period being 16 days. Total 05 Landsat-8 OLI images were downloaded from USGS website (Table 1). All the data of Landsat- 8 is acquired for the end of ablation period of the glacier. Further, the data selected is cloud free in glacier region and have minimum snow. Landsat-8 OLI images are a good source for monitoring high mountain glaciers. Therefore, in present study, Landsat-8 OLI PAN (15 m resolution) data is used to analyse surface velocity of Samudra Tapu Glacier during study period 2013-2017.

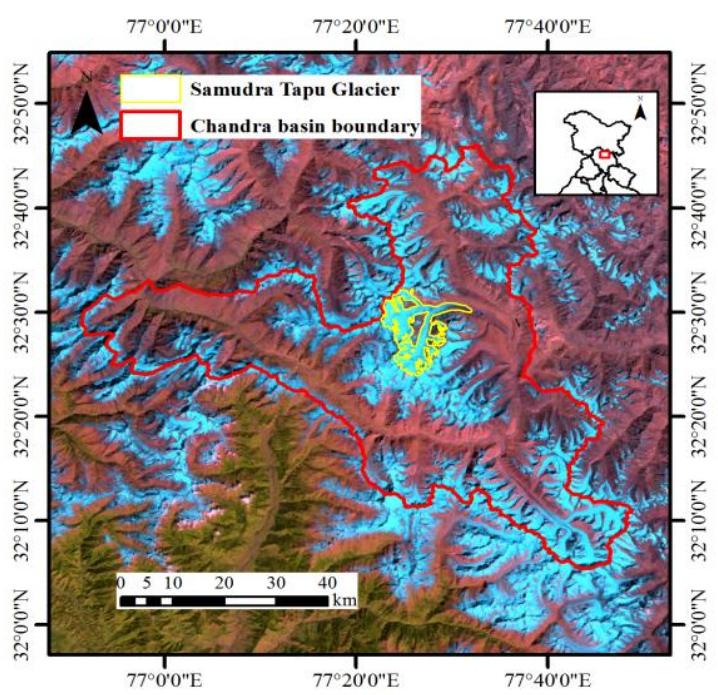

Figure 1. Location Map of Samudra Tapu Glacier in Chandra basin

\begin{tabular}{|l|c|c|}
\hline \multicolumn{1}{|c|}{ Sensor $\&$ Resolution } & \multicolumn{1}{c|}{ Date } & \multicolumn{1}{c|}{ Image Id } \\
\hline Landsat-8 OLI (PAN), 15m & 27-October-2013 & LC08_L1TP_147038_20131027_20170429_01_T1 \\
\hline Landsat-8 OLI (PAN), 15m & 28-September-2014 & LC08_L1TP_147038_20140928_20170419_01_T1 \\
\hline Landsat-8 OLI (PAN), 15m & 15-September-2015 & LC08_L1TP_147038_20150915_20170404_01_T1 \\
\hline Landsat -8 OLI (PAN), 15m & 03-October-2016 & LC08_L1TP_147038_20161003_20170319_01_T1 \\
\hline Landsat-8 OLI (PAN), 15m & 06-October-2017 & LC08_L1TP_147038_20171006_20171014_01_T1 \\
\hline
\end{tabular}

Table 1. Landsat-8 OLI (PAN) images used to estimate surface velocity

\section{METHODOLOGY}

In present study, surface velocity of Samudra Tapu Glacier is estimated through co-registration of optically sensed images using COSI-Corr correlation tool. This is an open source tool which work on cross-correlation algorithm and can be downloaded from http://www.tectonics.caltech.edu/slip_history /spot_coseis/download_software.html (Leprince et al., 2007). 
COSI-Corr tool was initially in use for monitoring tectonic displacements but later several researcher successfully applied this in glacier surface velocity estimation (Quincey et al., 2009a; Sahu and Gupta, 2019; Tiwari et al., 2014). The main principle of COSI-Corr algorithm is identification of common features in both images. For this purpose, two images of preevent and post event are selected, and common features are identified using desirable window on pre-event and post event images. This algorithm works on the frequency domain at subpixel level. This also minimises the error due to DEM inaccuracy, and increase the co-registration accuracy of images (Leprince et al., 2007).

Surface velocity estimation using COSI-Corr algorithm follows three steps process, namely, orthorectification, co-registration and correlation. Landsat-8 OLI PAN images are already orthorectified. Since Landsat-8 OLI images are used, hence there is no need to perform co-registration of these images in the present study. In COSI-Corr software, the optimum value of window size, step size and number of iterations is obtained iteratively using different parameter values for estimation of surface velocity. In correlation process, pre and post event images are first selected, then initial and final window size are selected as $64 * 64$ pixel and $32 * 32$ pixel respectively. Along with this, step size equal to 2 is chosen while the number of iterations is taken as 5. Correlation process is executed until common features are matched or till it reaches maximum iteration. Output of correlation process provides three images, i.e., North-South (N-S), East-West (E-W) and SNR (Signal to Noise Ratio) images. After this, all pixels having SNR $<0.9$ are removed using SNR file. The displacement map is generated using N-S and E-W images through the application of euclidean distance concept. To generate final surface velocity map, displacement is normalised on 365 day for annual basis, and surface velocity is then estimated in $\mathrm{m} / \mathrm{year}$. The flowchart of the methodology adopted is shown in figure 2 .

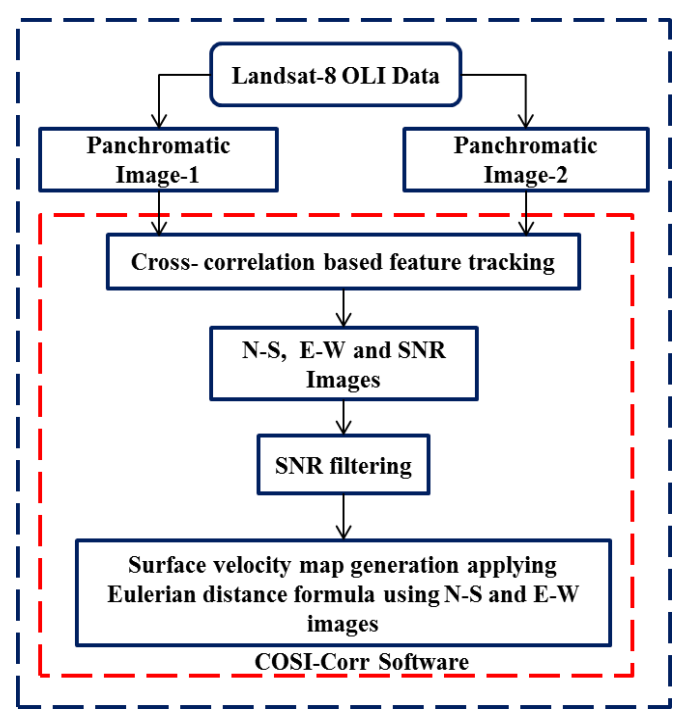

Figure 2. Methodology adopted

Surface velocity pattern can also be correlated by Hypsometric Index (HI) analysis. HI can be calculated as equation 1 and 2 (Jiskoot et al., 2009).

$$
H I=\frac{\left(E_{\max }-E_{\text {med }}\right)}{\left(E_{\text {med }}-E_{\text {min }}\right)}
$$

$$
\text { If } H I<1 \text { then } H I=\frac{-1}{H I}
$$

Where $\mathrm{E}_{\max }, \mathrm{E}_{\mathrm{med}}$ and $\mathrm{E}_{\min }$ are maximum, median and minimum elevation of Samudra Tapu Glacier respectively.

\begin{tabular}{|l|l|}
\hline \multicolumn{1}{|c|}{ HI Value } & \multicolumn{1}{c|}{ Glacier Type } \\
\hline $\mathrm{HI}<-1.5$ & Very top heavy \\
\hline$-1.5<\mathrm{HI}<-1.2$ & Top heavy \\
\hline$-1.2<\mathrm{HI}<1.2$ & Equidimensional \\
\hline $1.2<\mathrm{HI}<1.5$ & Bottom heavy \\
\hline $\mathrm{HI}>1.5$ & Very bottom heavy \\
\hline
\end{tabular}

Table 2. Glacier type based on HI value

\section{ERROR ESTIMATION}

Surface velocity estimation using COSI-Corr algorithm mainly experience three types of error. First one is due to orthorectification. However, in the present study, orthorectified Landsat-8 OLI images are acquired, so this error is already minimal and can't be further reduced. Second error occurs due to snow cover, cloud and melting glacier. This can be minimised by selecting satellite image having minimum snow and cloud as well as the image should be acquired at the end of ablation period. Third error can occur due to poor image contrast in images. To overcome this error, surface velocity is estimated only in ablation zone instead of accumulation zone (Bhushan et al., 2017; Garg et al., 2017; Paul et al., 2015).

To estimate the error in surface velocity estimation using COSICorr algorithm, non-glaciated area near to the terminus of the glacier is selected. It is assumed that surface velocity in nonglaciated stable area should be zero in ideal condition. Thus, mean surface velocity obtained in this non-glaciated stable area will be treated as an error in surface velocity estimation. In present study, total $\sim 750$ points are selected near the terminus and then mean surface velocity is estimated. This is the most common method to estimate the error in surface velocity, which has previously been used by various authors (Garg et al., 2017; Saraswat et al., 2013).

\section{RESULT AND DISCUSSION}

Surface velocity of Samudra Tapu Glacier is estimated during 2013 to 2017 using freely available 15m PAN images of Landsat-8 OLI sensor. Samudra Tapu Glacier boundary is taken from RGI 6.0 inventory. For better visualisation, SRTM-DEM based hillshade image is used as background image for surface velocity map. Surface velocity is estimated only in ablation area of the glaciers because more trackable features and good image contrast is available in this zone as compared to accumulation zone. This also increases the accuracy of velocity estimation (Sun et al., 2017). Mean annual surface velocity along the centre flow line during 2013 to 2017 are compiled in Table 3.

\begin{tabular}{|c|c|}
\hline Study duration & Surface velocity (m/year) \\
\hline $2013-2014$ & $53.79 \pm 4.71$ \\
\hline $2014-2015$ & $47.58 \pm 4.55$ \\
\hline $2015-2016$ & $55.68 \pm 4.01$ \\
\hline $2016-2017$ & $44.99 \pm 4.67$ \\
\hline Average (2013-2017) & $50.51 \pm 4.49$ \\
\hline
\end{tabular}

Table 3. Annual surface velocity 
In 2013-2014, annual surface velocity of Samudra Tapu Glacier was $53.79 \pm 4.71 \mathrm{~m} /$ year which decreased to $44.99 \pm 4.67$ $\mathrm{m} / \mathrm{year}$ in 2016-2017. However, annual surface velocity was $47.58 \pm 4.55 \mathrm{~m} /$ year and $55.68 \pm 4.01 \mathrm{~m} /$ year in 2014-2015 and 2015-2016 respectively. The average annual velocity computed during 2013-2017 was $50.51 \pm 4.49 \mathrm{~m} /$ year. This variation in surface velocity is largely effected by mass loss coupled with some other parameters i.e. temperature, pressure and basal drainage system (Usman and Furuya, 2018). For this purpose, seasonal surface velocity is also required along with long term (annual) surface velocity (Satyabala, 2016).

The surface velocity map of Samudra Tapu Glacier for the year 2013-2014, 2014-2015, 2015-2016 and 2016-2017, with hillshade image of SRTM DEM as background image is shown in figure 3. In figure 3(a), $\mathrm{AA}^{\prime}$ is the centre flow line and annual surface velocities are extracted along this centre flow line for further analysis. Maximum surface velocity is identified in upper ablation zone due to the mass transformation from its tributaries. It can be identified that from the terminus to till 1 $\mathrm{km}$, surface velocity was $<10 \mathrm{~m} / \mathrm{year}$ which indicate the stagnancy in surface velocity (figure 4). The main reason behind stagnancy in surface velocity is presence of debris covered ice, which is common characteristic of debris covered glaciers (Quincey et al., 2009b; Yan et al., 2018). In debris covered glacier, in lower ablation zone and near the terminus, maximum ice thickness reduction and surface lowering occur; and as a result stagnant low sloping downstream lower ablation zone appears (Benn et al., 2012). As shown in figure 5, as one moves opposite to glacier terminus, increasing trend is observed in the surface velocity and glacier elevation. Slope is showing a zigzag pattern. Still, it is increasing slightly till $4 \mathrm{~km}$ from terminus then decreased from $4 \mathrm{~km}$ to $4.5 \mathrm{~km}$, and then again showing slightly increasing pattern. However, the surface velocity is showing an increasing pattern. Garg et al (2017) have also observed increasing pattern. The error in surface velocity is estimated in non-glaciated stable area. The error varied from \pm 4.01 to $\pm 4.71 \mathrm{~m} /$ year during $2013-2017$ with mean error being $\pm 4.49 \mathrm{~m} /$ year.
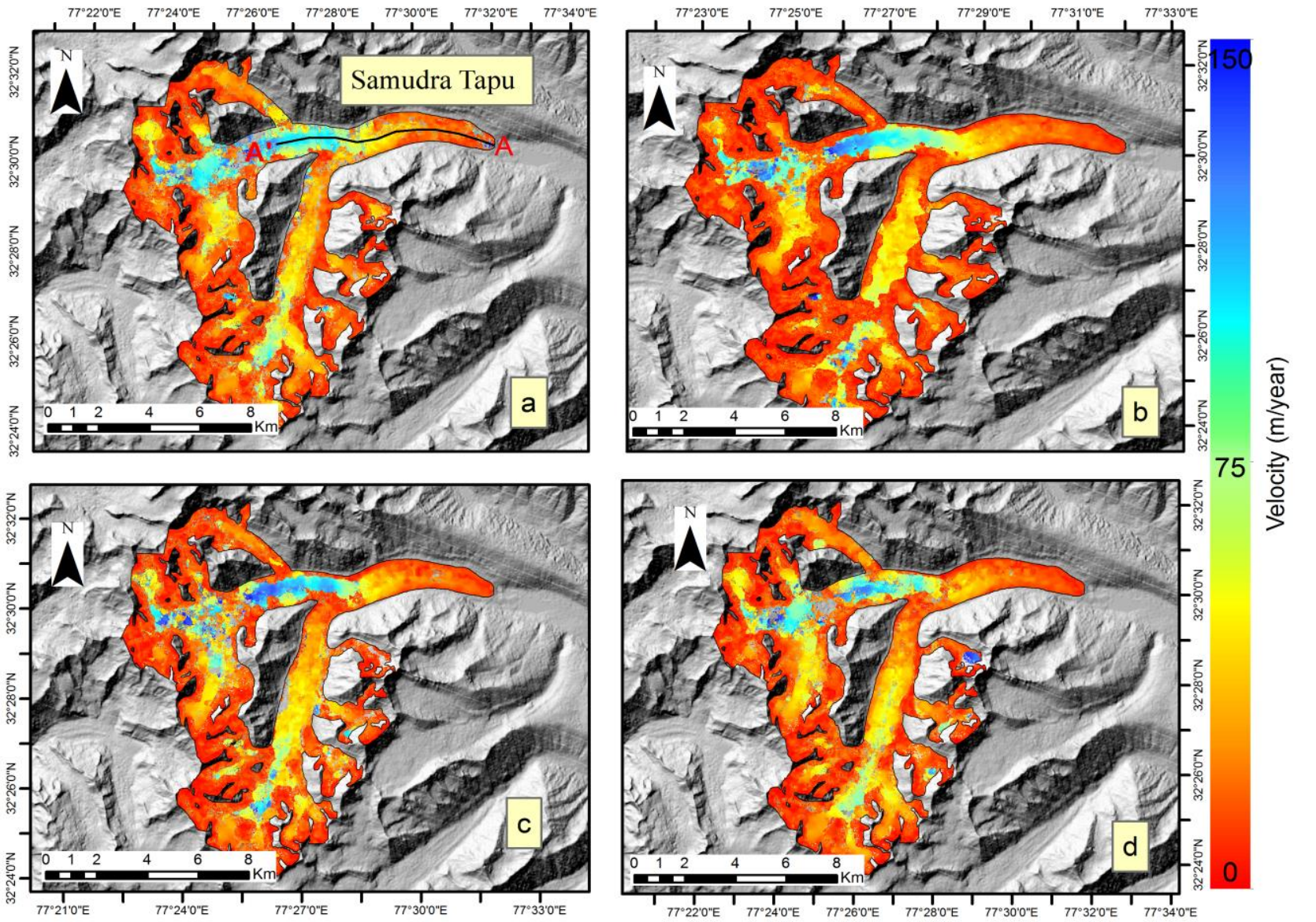

Figure 3. Surface velocity map of Samudra Tapu Glacier for the year (a) 2013-2014; (b) 2014-2015; (c) 2015-2016; (d) 2016-2017, with background image being a hillshade image of SRTM DEM 


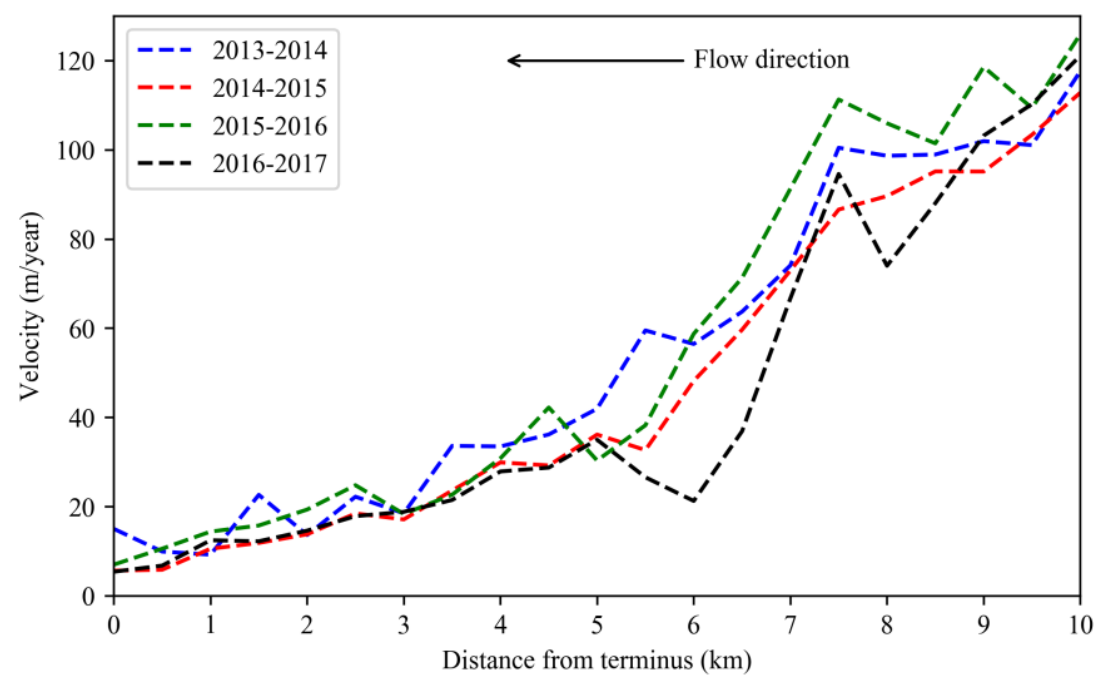

Figure 4. Annual surface velocity of Samudra Tapu Glacier during 2013-2017

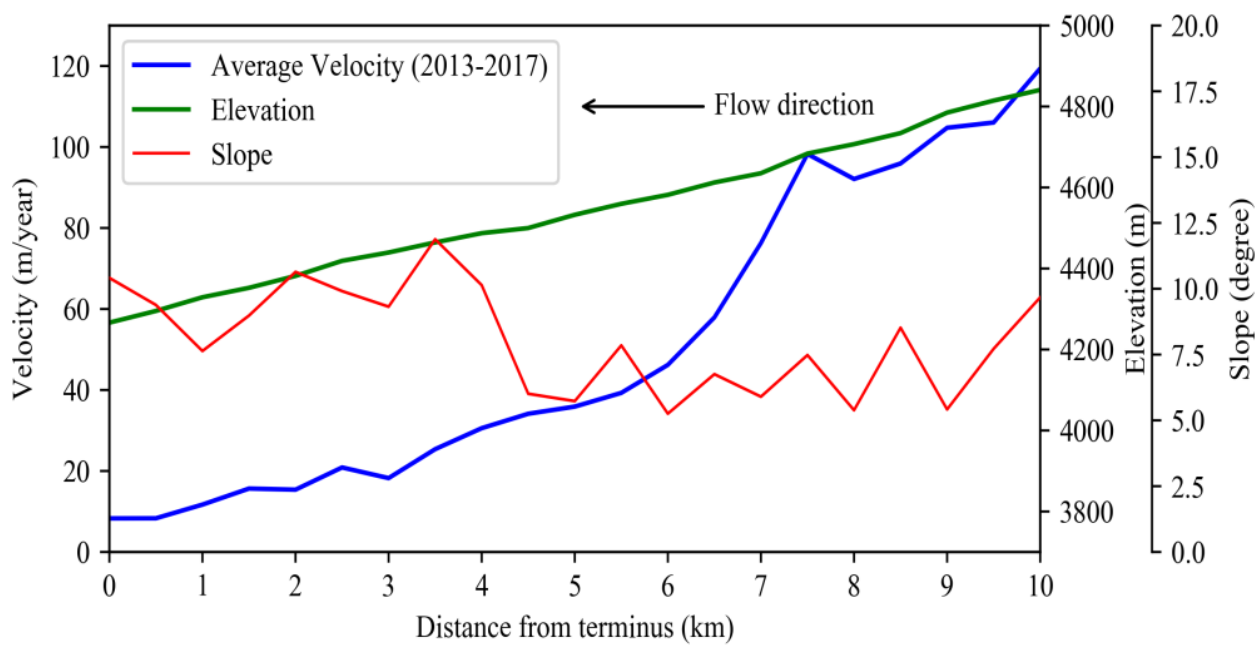

Figure 5. Average Surface velocity during 2013-2017 and its relation with elevation and slope

Surface velocity of Samudra Tapu Glacier is much larger than other glaciers in Chandra basin (Garg et al., 2017; Sahu and Gupta, 2019; Tiwari et al., 2014; Yellala et al., 2019). The surface velocity estimation for Samudra Tapu Glacier using remote sensing data or through field methods is also not available in the literature. To understand this behaviour, $\mathrm{HI}$ index analysis for Samudra Tapu Glacier is also carried out. The $\mathrm{HI}$ index of glacier is -1.204 which signifies that Samudra Tapu is top heavy glacier. Its shows that bottom $50 \%$ of Samudra Tapu Glacier area distribution span 1.204 times as much elevation as the top $50 \%$ of the area distribution. On this basis, Samudra Tapu Glacier is top heavy glacier in the sense that the area distribution is skewed toward top of elevation range (McGrath et al., 2017). Due to larger accumulation area, more mass is present in accumulation zone and larger amount of mass is available for movement (Quincey et al., 2009b). However, this one parameter alone is not responsible for higher surface velocity. The ice thickness also plays an important role for higher surface velocity which controls the basal movement of glacier (Paul et al., 2017). Thus, seasonal surface velocity and ice thickness information are also required to understand complete behaviour of Samudra Tapu Glacier in term of surface velocity.

\subsection{Comparison of surface velocity with other studies in Himalayan region}

Several studies have been carried out in different part of Himalaya. Bhattacharya et al. (2016) used Landsat TM, ETM+, OLI and ASTER data during 1993-2014 to estimate surface velocity of Gangotri Glacier. They estimated annual surface velocity $\sim 46 \pm 7.5 \mathrm{~m} /$ year $(1993-1994), \sim 50 \pm 7.2 \mathrm{~m} / \mathrm{year}$ (1998-1999), $\sim 48 \pm 4.8 \mathrm{~m} /$ year $(2008-2009)$ and $\sim 43 \pm 5.1$ m/year (2013-2014). Bhushan et al. (2017) also estimated surface velocity of Gangotri Glacier using Landsat ETM+, and OLI data as $42.42 \pm 6.28 \mathrm{~m} /$ year $(1999-2000)$, and $26 \%$ velocity reduction in 2013-2014 along the main trunk. Saraswat et al. (2013) also estimated surface velocity of Gangotri Glacier during 2004 - 2010 using ASTER images, and found minimum 
and maximum velocity as $13.9 \pm 2.3$ and $70.2 \pm 2.3 \mathrm{~m} /$ year. All studies on Gangotri Glacier show marginally less surface velocity as compared to Samudra Tapu Glacier. But studies carried out for other glaciers in Chandra basin have much lesser surface velocity, even up to half of Samudra Tapu Glacier (Garg et al., 2017; Sahu and Gupta, 2019; Tiwari et al., 2014; Yellala et al., 2019). Sahu and Gupta (2019) analysed four glaciers in Chandra basin, namely Chhota Shigri, Bara Shigri, Gepang Gath and Hamtah; and their average velocity during 2013-2017 was $20,20.79,10.53$ and $7.52 \mathrm{~m} /$ year respectively. In previous studies, it is observed that surface velocity of glacier is directly proportional to glacier thickness, and hence higher glacier ice thickness leads to higher surface velocity to (Cuffy and Paterson, 2010; Gantayat et al. 2014). In previous studies maximum ice thickness of Chhota Shigri, Hamtah and Samudra Tapu glaciers were found as $300 \mathrm{~m}, 95 \mathrm{~m}$ and $350 \mathrm{~m}$ respectively (Manya et al., 2016; Ramashankaran et al., 2018; Swain et al., 2018), thereby, validating our results.

\section{CONCLUSION}

In present study, annual surface velocity of Samudra Tapu Glacier is estimated using Ladsat-8 OLI PAN (15 m spatial resolution) images during 2013-2017. The surface velocity is estimated using open source COSI-Corr tool based on crosscorrelation algorithm. The average annual surface velocity of Samudra Tapu Glacier during 2013-2017 was 50.51 \pm 4.49 $\mathrm{m} /$ year. The annual surface velocity was maximum $(55.68 \pm$ $4.01 \mathrm{~m} /$ year $)$ in 2015-2016 while it was minimum (44.99 \pm 4.67 $\mathrm{m} / \mathrm{year}$ ) in 2016-2017. The annual surface velocity was $53.79 \pm$ $4.71 \mathrm{~m} /$ year and $47.58 \pm 4.55 \mathrm{~m} /$ year in 2013-2014 and 20142015 respectively. The annual variation in surface velocity not only depends on mass loss but also on temperature, pressure and basal drainage system. As one moves opposite to glacier terminus, the surface velocity increases with the increase in glacier elevation and slope. The present study will add value to the already existing research in the field of glacier dynamics for Chandra basin.

It is observed that surface velocity of Samudra Tapu Glacier is higher than other glaciers in Chandra basin. To understand this pattern, HI index analysis of Samudra Tapu Glacier was also carried out. The HI index of glacier is -1.204 which signifies that Samudra Tapu Glacier is top heavy glacier. Due to larger accumulation area, more mass is present in accumulation zone and larger amount of mass is available for movement. The ice thickness can also contribute to higher surface velocity which controls the basal movement of glacier, which can be taken up in future studies for better understanding glacier dynamics of Samudra Tapu glacier.

\section{REFERENCES}

Azam, M.F., Wagnon, P., Berthier, E., Vincent, C., Fujita, K., Kargel, J.S., 2018. Review of the status and mass changes of Himalayan- Karakoram glaciers. J. Glaciol. pp.1-14.

Benn, D.I., Bolch, T., Hands, K., Gulley, J., Luckman, A., Nicholson, L.I., Quincey, D., Thompson, S., Toumi, R., Wiseman, S., 2012. Response of debris-covered glaciers in the Mount Everest region to recent warming, and implications for outburst fl ood hazards. Earth Sci. Rev. 114,pp.156-174.

Bhattacharya, A., Bolch, T., Mukherjee, K., Pieczonka, T., Kropáček, J., Buchroithner, M.F., 2016. Overall recession and mass budget of Gangotri Glacier, Garhwal Himalayas , from 1965 to 2015 using remote sensing data. J. Glaciol. 63(236), pp.

\section{$1115-1133$}

Bhushan, S., Syed, T.H., Arendt, A.A., Kulkarni, A. V, 2018. Assessing controls on mass budget and surface velocity variations of glaciers in Western Himalaya. Sci. Rep. pp.1-11.

Bhushan, S., Syed, T.H., Kulkarni, A. V., Gantayat, P., Agarwal, V., 2017. Quantifying Changes in the Gangotri Glacier of Central Himalaya: Evidence for Increasing Mass Loss and Decreasing Velocity. IEEE J. Sel. Top. Appl. Earth Obs. Remote Sens. 10, pp.5295-5306.

Cuffey, K. M., Paterson W. S. B., 2010. The Physics of Glaciers. 4th ed. Oxford, UK: Butterworth-Heinemann.

Dehecq, A., Gourmelen, N., Gardner, A.S., Brun, F., Goldberg, D., Nienow, P.W., Berthier, E., Vincent, C., Wagnon, P., Trouvé, E., 2019. Twenty-first century glacier slowdown driven by mass loss in High Mountain Asia. Nat. Geosci. 12, pp.22-27.

Dehecq, A., Gourmelen, N., Trouve, E., 2015. Deriving largescale glacier velocities from a complete satellite archive: Application to the Pamir - Karakoram - Himalaya. Remote Sens. Environ. 162, pp.55-66.

Gantayat, P., Kulkarni, A. V., Srinivasan, J., 2014. Estimation of ice thickness using surface velocities and slope: Case study at Gangotri Glacier, India. J. Glaciol. 60,pp. 277-282.

Garg, P.K., Shukla, A., Kamal, R., Singh, A., 2017. Assessing the status of glaciers in part of the Chandra basin , Himachal Himalaya: A multiparametric approach. Geomorphology 284, pp.99-114.

Heid, T., Kääb, A., 2012. Evaluation of existing image matching methods for deriving glacier surface displacements globally from optical satellite imagery. Remote Sens. Environ.118, pp.339-355.

Jiskoot, H., Curran, C.J., Tessler, D.L., Shenton, L.R., 2009. Changes in Clemenceau Icefield and Chaba Group glaciers , Canada, related to hypsometry , tributary detachment, length slope and area - aspect relations. Ann. Glaciol. 50, pp.133-143.

Kulkarni, A. V., Dhar, S., Rathore, B.P., Babu Govindha Raj, K., Kalia, R., 2006. Recession of Samudra Tapu glacier, Chandra river basin, Himachal Pradesh. J. Indian Soc. Remote Sens. 34,pp. 39-46. https://doi.org/10.1007/BF02990745

Kumar, V., Venkataraman, G., Høgda, K.A., Larsen, Y., 2013. Estimation and validation of glacier surface motion in the northwestern Himalayas using high-resolution SAR intensity tracking. Int. J. Remote Sens. 34, pp.5518-5529.

Leprince, S., Ayoub, F., Klinger, Y., Avouac, J., 2007. CoRegistration of Optically Sensed Images and Correlation ( COSI-Corr ): An operational methodology for ground deformation measurements Co-Registration of Optically Sensed Images and Correlation (COSI-Corr): an Operational Methodology for Ground Deform. IEEE Xolore. pp.4-8.

Maanya, U. S. ,Kulkarni, A. V., Tiwari, A., Bhar, E. D., Srinivasan, J., 2016. Identification of potential glacial lake sites and mapping maximum extent of existing glacier lakes in Drang Drung and Samudra Tapu glaciers, Indian Himalaya. Curr. 


\section{Sci.111,pp.553-560.}

McGrath, D., Sass, L., O’Neel, S., Arendt, A., Kienholz, C., 2017. Earth' s Future Hypsometric control on glacier mass balance sensitivity in Alaska and northwest Canada Earth's Future. Earth's Futur. 5, pp.324-336.

Mukherjee, K., Bhattacharya, A., Pieczonka, T., Ghosh, S., Bolch, T., 2018. Glacier mass budget and climate reanalysis data indicate a climatic shift around 2000 in Lahaul-Spiti, western Himalaya. Clim. Change 148,pp.219-233. https://doi.org/10.1007/s10584-018-2185-3

Pandey, P., Venkataraman, G., 2013. Changes in the glaciers of Chandra - Bhaga basin , Himachal Himalaya , India , between 1980 and 2010 measured using remote sensing. Int. J. Remote Sens. 34,pp.5584-5597. https://doi.org/10.1080/01431161.2013.793464

Paul, F., Bolch, T., Kääb, A., Nagler, T., Nuth, C., Scharrer, K., Shepherd, A., Strozzi, T., Ticconi, F., Bhambri, R., Berthier, E., Bevan, S., Gourmelen, N., Heid, T., Jeong, S., Kunz, M., Lauknes, T.R., Luckman, A., Merryman Boncori, J.P., Moholdt, G., Muir, A., Neelmeijer, J., Rankl, M., Vanlooy, J., Van Niel, T., Rune, T., Luckman, A., Peter, J., Boncori, M., Moholdt, G., Muir, A., Neelmeijer, J., Rankl, M., Vanlooy, J., Niel, T. Van, 2015. The glaciers climate change initiative: Methods for creating glacier area, elevation change and velocity products. Remote Sens. Environ. .162, pp.408-426.

Paul, F., Strozzi, T., Schellenberger, T., Kaab, A., 2017. The 2015 surge of hispar glacier in the karakoram. Remote Sens. 9, pp.1-18.

Prakash, C., Nagarajan, R., 2018. Glacial lake changes and outburst flood hazard in Chandra basin, North-Western Indian Himalaya. Geomatics, Nat. Hazards Risk 9, pp.337-355.

Quincey, D.J., Copland, L., Mayer, C., Bishop, M., Luckman, A., Belo, M., 2009a. Ice velocity and climate variations for Baltoro Glacier, Pakistan. J. Glaciol. 55, pp.1061-1071.

Quincey, D.J., Luckman, A., Benn, D., 2009b. Quantification of Everest region glacier velocities between 1992 and 2002, using satellite radar interferometry and feature tracking. J. Glaciol. 55, pp.596-606.

Ramsankaran, R., Pandit, A., Azam, F., 2018. Spatially distributed ice-thickness modelling for Chhota Shigri Glacier in western Himalayas, India, Int. J. Remote Sens, 39:10, 33203343.

Sahu, R., Gupta, R.D., 2019. Spatiotemporal variation in surface velocity in Chandra basin glacier between 1999 and 2017 using Landsat-7 and Landsat-8 imagery. Geocarto Int.

Saraswat, P., Syed, T.H., Famiglietti, J.S., Fielding, E.J., Crippen, R., Gupta, N., 2013. Recent changes in the snout position and surface velocity of Gangotri glacier observed from space. Int. J. Remote Sens. 34, pp.8653-8668.

Satyabala, S.P., 2016. Spatiotemporal variations in surface velocity of the Gangotri glacier, Garhwal Himalaya, India: Study using synthetic aperture radar data. Remote Sens. Environ. 181, pp.151-161.
Sun, Y., Jiang, L., Liu, L., Sun, Y., Wang, H., 2017. SpatialTemporal Characteristics of Glacier Velocity in the Central Karakoram Revealed with 1999 - 2003. Remote Sens. 9, pp.120.

Swain AK, Mukhtar MA, Majeed Z, Shukla SP. 2017. Depth profiling and recessional history of the Hamtah and Parang glaciers in Lahaul and Spiti, Himachal Pradesh, Indian Himalaya. Himal Cryosphpast Present. 462.

Tiwari, R.K., Gupta, R.P., Arora, M.K., 2014. Estimation of surface ice velocity of Chhota- Shigri glacier using sub-pixel ASTER image correlation. Curr. Sci. 106, pp.853-859.

Usman, M., Furuya, M., 2018. Interannual modulation of seasonal glacial velocity variations in the Eastern Karakoram detected by ALOS-1 / 2 data. J. Glaciol. 64, pp.465-476.

Vijay, S., Braun, M., 2016. Elevation Change Rates of Glaciers in the Lahaul-Spiti ( Western Himalaya , India ) during. Remote Sens. 8. https://doi.org/10.3390/rs8121038

Yan, S., Li, Y., Li, Z., Liu, G., Ruan, Z., Li, Z., 2018. An insight into the surface velocity of Inylchek Glacier and its effect on Lake Merzbacher during 2006-2016 with Landsat time-series imagery. Environ. Earth Sci. 77 (773), pp.1-10.

Yasuda, T., Furuya, M., 2013. Remote Sensing of Environment Short-term glacier velocity changes at West Kunlun Shan , Northwest Tibet, detected by Synthetic Aperture Radar data. Remote Sens. Environ. 128, pp.87-106.

Yellala, A., Kumar, V., Høgda, K.A., 2019. Bara Shigri and Chhota Shigri glacier velocity estimation in western Himalaya using Sentinel-1 SAR data Bara Shigri and Chhota Shigri glacier velocity estimation in. Int. J. Remote Sens. 40, pp.58615874. 